\title{
ENDOREPLICATION: A MOLECULAR TRICK DURING ANIMAL NEURON EVOLUTION
}

\author{
MaUro Mandrioli \\ Department of Biology, University of Modena and Reggio Emilia, 41100 Modena, Italy \\ E-MAIL: MAURO.MANDRIOLI@UNIMO.IT \\ Lucrezia Mola \\ Department of Biology, University of Modena and Reggio Emilia, 41100 Modena, Italy \\ E-MAIL: LUCREZIA.MOLA@UNIMO.IT
}

\section{Barbara Cuoghi}

Department of Biology, University of Modena and Reggio Emilia, 41100 Modena, Italy E-MAIL: BARBARA.CUOGHI@UNIMO.IT

\section{DARIO SONETTI}

Department of Biology, University of Modena and Reggio Emilia, 41100 Modena, Italy E-MAIL: DARIO.SONETTI@UNIMO.IT

KEYWORDS

DNA endoreplication, neuron evolution, mollusc, fish, nervous system

\section{ABSTRACT}

The occurrence of endoreplication has been repeatedly reported in many organisms, including protists, plants, worms, arthropods, molluscs, fishes, and mammals. As a general rule, cells possessing endoreplicated genomes are large-sized and highly metabolically active. Endoreplication has not been frequently reported in neuronal cells that are typically considered to be fully differentiated and non-dividing, and which normally contain a diploid genome. Despite this general statement, various papers indicate that giant neurons in molluscs, as well as supramedullary and hypothalamic magnocellular neurons in fishes, contain DNA amounts larger than 2C. In order to study this issue in greater detail here, we review the available data about endoreplication in invertebrate and vertebrate neurons, and discuss its possible functional significance. As a whole, endoreplication seems to be a sort of molecular trick used by neurons in response to the high functional demands that they experience during evolution.

The Quarterly Review of Biology, June 2010, Vol. 85, No. 2 Copyright (C) 2010 by The University of Chicago Press. All rights reserved. 0033-5770/2010/8502-0002\$15.00 


\section{INTRODUCTION}

$\mathrm{E}$ NDOREPLICATION is a widespread phenomenon observed among protists, plants, and animals, including arthropods, worms, molluscs, and mammals (Edgar and Orr-Weaver 2001). Endoreplicating cells can increase their $\mathrm{C}$ values - thereby indicating the DNA contents as a multiple of the normal haploid genome size-as high as 24,000C, for example, as in some plants (Traas et al. 1998). Considering that nuclear and, consequently, cell size are generally proportional to the amount of nuclear DNA, cell growth can be differentially regulated using the ploidy level, thus making endoreplication a common feature in differentiated cells that are large-sized and/or highly metabolically active (Edgar and Orr-Weaver 2001).

Endoreplication has been thoroughly studied in Drosophila melanogaster, where many organs (such as the gut, epidermis, fat body, Malpighian tubules, trachea, and salivary glands) initiate endoreplication following the cell-proliferation phase of embryogenesis (White 1973; Smith and Orr-Weaver 1991, Lilly and Duronio 2005; NarbonneReveau et al. 2008). These organs continue to endoreplicate during larval development, long after they are fully differentiated. Some adult cells, including ovarian follicle cells, nurse cells, and the sensory neurons in the wing, also endoreplicate, so that the final DNA levels in the larval cells are developmentally programmed (Edgar and Orr-Weaver 2001).

Cell types that undergo endoreplication were also identified in vertebrates, particularly in mammals (Edgar and Orr-Weaver 2001). An example can be found in megakaryocytes that become polyploid up to $128 \mathrm{C}$ as a part of their differentiation process in order to increase their ability to bud-off large numbers of platelets (Zimmet and Ravid 2000). A second mammalian cell type that undergoes endoreplication is the trophoblast, which contributes to the placenta and increases its DNA contents up to more than 1000C, presumably to face a high metabolic demand (Varmuza et al. 1988; Zybina and Zybina 1996). Some researchers have also reported that the cerebellar Purkinje cells in vertebrates possess endoreplicated ge- nomes. Indeed, DNA contents higher than 2C were reported for several different species across various studies (e.g., Herman and Lapham 1969; Bohn and Mitchell 1976; Bernocchi and Barni 1985; Del Monte 2006). At the same time, however, other researchers have pointed out that the DNA amount in these cells corresponds to the normal 2C (e.g., Cohen et al. 1973; Mares et al. 1973; Fujita et al. 1974; Fukuda et al. 1978; Mann et al. 1978), therefore making it difficult to draw a definitive conclusion about the real occurrence of endoreplication in this cell type.

For a long time, neurons had been considered "stable cells," as they are non-dividing and remain 2C throughout their entire lifetime- - thus, they are fully differentiated. This view changed in the early 1990s, when it was discovered that the role of neurons in brain repair and brain plasticity appeared to be much more complex and articulated than had been previously expected. Indeed, even though endoreplication had not been frequently reported in neuronal cells, several works proved that giant neurons in molluscs and supramedullary and hypothalamic magnocellular neurons in fishes present DNA contents greater than 2C. Here we review the available data about endoreplication in vertebrate and invertebrate giant neurons, in order to study this issue in more detail.

\section{Giant Endopolyploid Neurons in INVERTEBrates: The CASE OF Gastropod MOlluscs}

Giant neurons are scattered across several invertebrate species, starting with nematodes and annelids (for a review see Bullock and Horridge 1965), but only in a few cases has the large neuronal size been specifically associated with an increased amount of DNA. A couple of very large neurons (100-120 $\mu \mathrm{m})$, the serotonergic Retzius cells of the leech Hirudo medicinalis, are probably the first examples of electrophysiologically and biochemically well-characterized giant neurons (Gaskell 1919; Coggeshall 1972). Large-sized neurons are also present in arthropodssuch as Diptera, Odonata, Chelicerata, and Arachnoidea-possessing giant cells that have been identified as motor elements (Bullock 
TABLE 1

Suggested mechanisms for genome increase, cell sizes, and maximum DNA content found in molluscs

\begin{tabular}{|c|c|c|c|c|}
\hline Species & $\begin{array}{l}\text { Mechanism involved } \\
\text { in genome increase }\end{array}$ & $\begin{array}{c}\text { Maximum cell } \\
\text { size (diameters) }\end{array}$ & $\begin{array}{l}\text { Maximum DNA } \\
\text { amount recorded }\end{array}$ & References \\
\hline Achatina fulica** & Partial amplification & $28 \mu \mathrm{m} \dagger$ & $128 \mathrm{C}$ & $\begin{array}{l}\text { Chase and Tolloczko } \\
\text { (1987) }\end{array}$ \\
\hline Aplysia californica* & Complete polyploidy & $1000 \mu \mathrm{m}$ & More than $200,000 \mathrm{C}$ & Lasek and Dower (1971) \\
\hline Helix pomata** & Complete polyploidy & $200 \mu \mathrm{m}$ & More than $500 \mathrm{C}$ & $\begin{array}{l}\text { Manfredi Romanini } \\
\text { et al. (1972) }\end{array}$ \\
\hline Lymnaea stagnalis** & Complete polyploidy & $90 \mu \mathrm{m}$ & $4096 \mathrm{C}$ & Boer et al. (1977) \\
\hline Planorbarius corneus** & Partial amplification & $80 \mu \mathrm{m}$ & More than $1000 \mathrm{C}$ & $\begin{array}{l}\text { Lombardo and Sonetti } \\
\qquad(1977,1983)\end{array}$ \\
\hline Succinea lauta** & Complete polyploidy & $380 \mu \mathrm{m}$ & $16,384 \mathrm{C}$ & $\begin{array}{l}\text { Kirsanova and Anisimov } \\
\text { (2000) }\end{array}$ \\
\hline Triodopsis divesta** & Complete polyploidy & n. d. & $32 \mathrm{C}$ & Cowden (1972) \\
\hline
\end{tabular}

Note:

*Opistobranchs

***ulmonates.

†At present, the genome size has been evaluated in neurons of $28 \mu \mathrm{m}$ only.

n. d. = size not determined.

and Horridge 1965), but this does not constitute a rule among invertebrates.

A special case among invertebrates is certainly represented by the occurrence of giant neurons with a DNA content much higher than diploid in the most evolved gastropod molluscs-Opisthobranchia and Pulmonata. These neurons seemingly do not occur in even the primitive Prosobranchia that have been thus far examined (Table 1). In Opisthobranchia and Pulmonata, a clear centralization in the head of the nervous system is constituted by a periesophageal ring of functionally distinct ganglia joined together by nervous connectives and commissures (Figure 1). The giant neurons are found in the central ganglia of each species, located in the cortex layer in constant number and position. Fewer giant neurons occur in the buccal, pleural, and cerebral ganglia, whereas the most occur in the visceral and pedal ganglia. They are intermingled with a heterogeneous population of neurons and glial cells; indeed, even if some diploid nerve cells are small, the majority of neurons occur in a wide range of sizes, and their DNA content directly correlates to nuclear size. Bullock and Horridge (1965) described gastropod giant neurons in their fundamental handbook and stated that they are "extraordinary in providing the basis of a disproportionate fraction of our knowledge of neuronal cytology, because of the large size and accessibility of some of them" (p. 981). "The largest cells are veritable giants, not only relative to others in the same animals but to the nerve cells in any group of animals and indeed to active cells in general, attaining diameters of $0.8 \mathrm{~mm}$ and more" (Bullock and Horridge 1965). Interestingly, these authors also say "they (the large and giant neurons) are especially notable for the size of the nucleus, which is commonly about two-thirds of the diameter of the cell" (Bullock and Horridge 1965:981). Some years later, this occurrence was clearly associated with endoreplication, as shown for the first time by Coggeshall et al. (1970).

The most studied giant gastropod neurons belong to the sea-hare Aplysia californica, a marine opisthobranch that became quite well-known through the fundamental studies of Kandel and his group in the 1960s (Frazier et al. 1967). They adopted this animal as a model for investigating the cellular and molecular basis of behavior focusing mainly on the abdominal ganglion, where they identified and mapped all of the single giant and large neurons (about 30) aside from the most prominent 

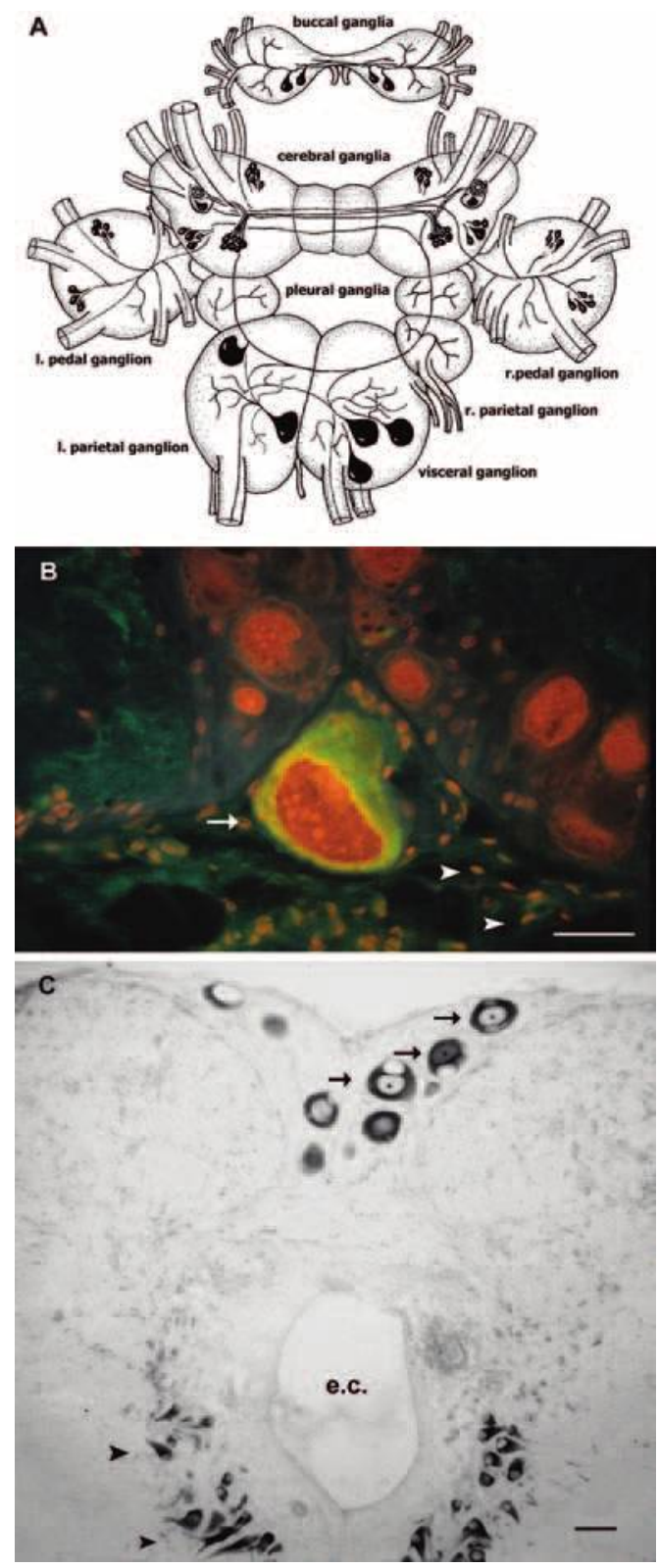

Figure 1. Giant Neurons in the Gastropod and Fish Nervous Systems

(A) Schematic dorsal representation of the centralized nervous system of the gastropod freshwater snail Planorbarius corneus, showing some giant neurons (70-100 $\mu \mathrm{m}$ in size) and several clusters of smaller nerve cells localized for their immunopositivity for ACTH. (B) A cross-section through the left parietal ganglion of $P$. corneus showing a giant neuron, as indicated by the arrow, that is positively immuno-fluorescent (FITC fluorophore) for endogenous morphine. The picture shows the nuclei fluorescent in red, stained with propidium iodide. Note the difference in size between the giant neuron nucleus and the much smaller nuclei of glial immunonegative cells, as indicated by the arrowheads. Bar: $50 \mu \mathrm{m}$. (C) Transversal section of rostral spinal cord of Diodon holacanthus showing the supramedullary neurons clustered (arrows) in the dorsal region as well as the motor neurons (arrowheads). e.c.: ependymal canal. Bar: $100 \mu \mathrm{m}$. 
cell clusters. The largest neurons they found were named L10 and R2, and were reported to have a soma diameter of almost $1 \mathrm{~mm}$ in adults and to contain an ellipsoid nucleus with a long axis of up to $800 \mu \mathrm{m}$, which reached a volume of about $10^{6} \mu \mathrm{m}^{3}$ and was thus visible in vivo, even by the naked eye, due to natural pigmentation and refraction. These large, identifiable cells are already well distinguishable in the ganglia of small juveniles specimens and do not change in number; rather, they simply increase in size during the course of the animal's life, in contrast to the small-sized neuron class, which only seems to increase in number.

Through cytophotometric analysis, Coggeshall et al. (1970) found that the DNA contents of $A$. californica giant neurons can vary during development from 2000C to $75,000 \mathrm{C}$ by incremental duplications of the whole genome, thus supporting the hypothesis that polyploidy may take place. These data were successively confirmed by fluorimetric analyses, which showed that $A$. californica giant neurons may contain amounts of DNA up to 260,000C times higher than the haploid $\mathrm{C}$ value present in spermatozoa, thereby corresponding theoretically to $16-17$ complete replications (Lasek and Dower 1971).

The increase in size of the large neurons has been explained as a part of an intrinsic response to an increased functional demand for innervating larger areas of the growing body (Gillette 1991). As Kandel (1976) stated, "Some (neuronal) cell types, often large cells, may never vary in number because they never experience demands for functional elaboration, or if they do they respond [by] enlarging and undergoing DNA replication but not cellular replication" (p. 727). Quantitative analysis of large nuclei performed on Feulgen DNAstained preparations revealed the occurrence of repeated duplication of the complete genome in other gastropods, viz. the pulmonates Helix pomatia (Kuhlman 1969; Manfredi Romanini et al. 1972), Lymnaea stagnalis (Boer et al. 1977), Triodopsis divesta (Cowden 1972), and Succinea lauta (Kirsanova and Anisimov 2000), that prompted a number of further studies supporting the oc- currence of complete genome duplications in giant neurons (for review see Brodsky and Uryvaeva 1985$)$.

A different situation was found, in contrast, in the giant neurons of the freshwater snail Planorbarius comeus and the land snail Achatina fulica, where apparently only part of the genome is duplicated (Lombardo et al. 1980; Lombardo and Sonetti 1983; Chase and Tolloczko 1987). Cytochemical and microfluorimetric analyses performed on the nervous system of $P$. corneus were able to distinguish GC-rich from AT-rich DNA strands, and these results suggested that the increase in DNA content could be correlated with an increase in nuclear volume due to a higher differential amplification of GC-rich DNA sequences in specific compartments of the genome. This hypothesis was supported by data reporting that, in $P$. comeus, the increase in nuclear volume is associated with an increase in nucleolus number and in the amount of correspondent perinucleolar chromatin that is generally reported as GC-rich (Lombardo and Sonetti 1977).

As Chase and Tolloczko (1987) observed in Achatina, a "differential DNA endoreplication" of some DNA sequences takes place at a higher rate in juvenile specimens, particularly during the period of the animal's greatest growth, but declines rapidly following the onset of sexual maturity. In their microspectrophotometric DNA content determinations, these researchers considered neuronal nuclei with diameters up to $28 \mu \mathrm{m}$ for technical limits, but they did not encounter discrete size classes corresponding to a simple doubling (Chase and Tolloczko 1987). Furthermore, the analysis of quantitative data reported for measurements of different neuronal size classes and/or different animal age/size classes in Planorbarius and Achatina suggested that complete genome replication and differential amplification of specific sequences could both run in concert, thus keeping the two processes coupled or unmatched. It could be very interesting to revisit these data using new molecular techniques, such as the Real Time PCR, in order to experimentally test such a hypothesis. 
Functional explanations supporting the differential amplification of parts of the genome in molluscs might entail genes involved in the synthesis of particular molecules, proteins, or RNAs that are required for a rapid biosynthesis of specific gene products. Alternatively, the amplified genes might be involved in a more aspecific mechanismfor instance, the production of a considerable amount of rRNA aimed to increase the protein synthesis capacity. Picciotto et al.'s (1986) investigations of $A$. californica seem to exclude a differential amplification of genes that encode specific neuropeptides.

\section{Giant Endopolyploid Neurons in Teleosts}

With regard to extra DNA content in teleost neurons, endoreplication phenomena were suggested in the hypothalamic magnocellular neurons in the preoptic and tuberal complexes (Benedetti et al. 1999) of the angler fish Lophius piscatorius and in the long-spine porcupinefish Diodon holacanthus. Computerized image analysis on histological sections treated with Feulgen reaction showed a correlation between the increase in nuclear area of the neurosecretory neurons and the increase in their Feulgen-DNA content. Microfluorimetric analysis on slides treated with ethidium bromide staining demonstrated that the hypothalamic neurons have nuclei whose DNA content increases with an increase in their size, reaching values of about $68 \mathrm{C}$ in L. piscatorius and about $84 \mathrm{C}$ in D. holacanthus (Benedetti et al. 1999). Moreover, the analysis of $\mathrm{C}$ values and percent distributions of hypothalamic neuron nuclei suggested that the increase in DNA amounts might be due to differential gene amplification (Benedetti et al. 1999).

The most unexpected finding involves DNA endoreplication occurrence in teleost supramedullary neurons $(\mathrm{SN})$, which are giant neurons composing a particular neuronal group belonging to the autonomic nervous system (Mola and Cuoghi 2004). In the pufferfish Takifugu niphobles, SN-free nerve endings were detected in the skin near mucous glands (Funakoshi et al. 1998); consequently, $\mathrm{SN}$ were thought to act as mucous secretion agents in fish chemical defenses against parasites or predators (Zottoli et al. 1999).

$\mathrm{SN}$ are located on the dorsal surface of the spinal cord of various species of teleosts. In Clupeiformes, Syngnatiformes, Scorpaeniformes, Pleuronectiformes, and Perciformes orders, SN are aligned along the spinal cord, whereas they are clustered at the rostral spinal cord in Tetraodontiformes (Figure 1C), Lophiiformes, and Batrachoidiformes (for a complete review, see Mola and Cuoghi 2004). Although ultrastructural features are quite similar for $\mathrm{SN}$ belonging to all the different species and orders examined up until now, SN morphology, number, and size are unique to each species (Mola and Cuoghi 2004). For instance, Solea ocellata SN have recently been demonstrated as a transitional form, neither singularly aligned nor authentically clusterized, but instead forming small groups of two or three SN alternate to singular SN (Cuoghi and Mola 2007). These morphological observations give us descriptive data, but also furnish functional information, since only clustered SN (Sassi et al. 1995; Mola et al. 2001) and S. ocellata SN (Cuoghi and Mola, 2007) have a supranormal DNA amount.

Feulgen reaction and fluorimetric analyses performed on nuclei of clustered SN of D. holacanthus and L. piscatorius indicated that the DNA amount is a multiple of the normal diploid quantity (2C), and it is always matched with the sizes of the nucleus, cell, and animal. In particular, DNA content in D. holacanthus SN can reach more than 500C (Mola et al. 2001), and even 5000C in L. piscatorius specimens (Sassi et al. 1995). Also, clustered SN in Tetraodon fluviatilis have a DNA content higher than 2C (Cuoghi, unpublished data). Accordingly, recent results for $S$. ocellata $\mathrm{SN}$, obtained with cytofluorimetric evaluation, indicated DNA content ranging from $6 \mathrm{C}$ in smaller $\mathrm{SN}$ to $100 \mathrm{C}$ in larger SN (Cuoghi and Mola 2007) (Table 2). It can therefore be inferred that DNA supra-normal content is a common characteristic of all clustered SN.

The DNA amplification in D. holacanthus 
TABLE 2

Disposition, number, and DNA content of giant neurons in fish

\begin{tabular}{llccccc}
\hline & \multicolumn{1}{c}{ SN } & Total SN & $\begin{array}{c}\text { SN size } \\
\text { (medium } \\
\text { diameters) }\end{array}$ & $\begin{array}{c}\text { Nucleus } \\
\text { size } \\
\text { (medium } \\
\text { diameters) }\end{array}$ & $\begin{array}{c}\text { Maximum } \\
\text { DNA amount } \\
\text { recorded }\end{array}$ & 2C value \\
\hline Lophius piscatorius & Clusterized & More than 200 & $90 \times 105 \mu \mathrm{m}$ & $35 \times 40 \mu \mathrm{m}$ & More than 5000 C & $2,04 \mathrm{pg}$ \\
Diodon holacanthus & Clusterized & 200 & $65 \times 75 \mu \mathrm{m}$ & $35 \times 45 \mu \mathrm{m}$ & More than 500 C & $1,56 \mathrm{pg}$ \\
Solea ocellata & Small groups & 70 & $120 \times 80 \mu \mathrm{m}$ & $60 \times 40 \mu \mathrm{m}$ & 100 C & $1,46 \mathrm{pg}$ \\
\hline
\end{tabular}

Note: Disposition, total number, cell and nucleus sizes, and maximum DNA content of supramedullary neurons found in the three different teleost species examined, with 2C values for each species.

and L. piscatorius $\mathrm{SN}$ does not take in the complete genome, but occurs only for specific genes (Sassi et al. 1995; Mola et al. 2001). Nucleolar organizing region (NOR) staining, carried out with the aim of testing the involvement of NORs in the growth of nucleolar area, showed that each neuron in a cluster contains a large nucleolus. The nucleolar ultrastructural data, together with silver NOR staining, suggested an intense production of ribosomal components (Sassi et al. 1995; Cuoghi and Marini 2001); indeed, it is generally accepted that silver staining reveals transcriptional activity of ribosomal genes (Howell 1977; Hubbel 1985), or at least the transcriptional potential of such genes (Sumner 1990). The clustered SN, as in those of $S$. ocellata as well, are giant cells (larger than the aligned SN) with high metabolic rates, as suggested by ultrastructural features (Cuoghi 2001; Cuoghi and Marini 2001) and by cytochemical tests that demonstrate the presence of multiple signalling molecules, such as noradrenaline, ACTH-like peptide, CCK-like peptide, and nitric oxide (Mola and Cuoghi 2004; Cuoghi and Mola 2007). Therefore, we hypothesize that clustered SN (including those of $S$. ocellata) developed high DNA contents through an increased production of ribosomes in order to satisfy their high metabolic rates. Accordingly, the data on hypothalamic neurosecretory neurons in L. piscatorius and D. holacanthus indicate that a marked increase of DNA content is not an exclusive feature of $\mathrm{SN}$, as the two cell types share a large size and an intense biosynthetic activity (neurohormones and neurotransmitters, respectively).
What genome regions are amplified in clustered SN? There is not one simple answer to this question. Chromomycin $\mathrm{A}_{3}\left(\mathrm{CMA}_{3}\right)$ and 4',6'-Diamino-2-phenylindole (DAPI) staining followed by microfluorimetric evaluations suggested that, in L. piscatorius, the amplification occurs with regard to GC-rich sequences (Sassi et al. 1995), but the same does not hold true for D. holachantus SN (Mola et al. 2001). Even if staining with fluorochromes presents several limitations, this discrepancy does not seem to be related to the fluorimetric method, but could instead be related to genes that are passively amplified simply due to their proximity to the important genes. In other words, the difference in results obtained for two phylogenetically distinct fish species could simply reflect differences in their genomic organization.

\section{Conclusions and Perspectives}

Fluorimetric analyses reported the occurrence of endoreplication in neurons of phylogenetically unrelated species; it is not easy, therefore, to provide a unique explanation for the role of endoreplication during evolution. The use of microfluorimetric measurements cannot furnish a very accurate measure of the degree of endoreplication that can be evaluated using genomic approaches, thus bringing with it a risk of over-estimation in the degree of endoreplication, but providing convincing evidence of endoreplication in neurons nonetheless, so that the occurrence of endoreplication rather than its estimate can be properly discussed.

In this regard, at least two generalizations can be made according to previous 
papers (Edgar and Orr-Weaver 2001; Anisimov 2005). First, endoreplication seems to be typical for large, metabolically active cells, suggesting that it is an effective tool for allowing cells to increase their mass or metabolic output (Edgar and Orr-Weaver 2001). Second, since endoreplication permits growth without periodic rearrangements of cytoskeletal elements or cell-cell contacts, as occur in mitosis, it may cause relatively little disruption to the structure of a differentiated tissue. Together, these properties make endoreplication an advantageous strategy for cells and tissues that, although strongly differentiated, still must continue to grow (Edgar and Orr-Weaver 2001). These features are extremely important to neurons that are fully differentiated, non-dividing cells because they could increase their functional plasticity without disrupting the structure of the nervous system.

The analysis of endoreplication phenomena in neurons allows us to obtain some insight into its frequency. First, it should be emphasized that giant or largesized neurons, although found in a wide variety of invertebrate and vertebrate species, generally do not occur very frequently. If the occurrence of endoreplication is considered from an evolutionary perspective, it seems to have been "re-invented" several times. An important question is: why do giant neurons choose endoreplication? That is, why do neurons belonging to particular systems become giant cells with very high DNA contents and impressive "metabolic machines" instead of forming more numerous, normally diploid neurons during development? For these cells, endoreplication must be a very useful and economically profitable way to overcome high metabolic demands, as it is present in species phylogenetically distant from one another, and has therefore arisen independently, more than once, during evolution.

As suggested by Anisimov (2005), the single giant neuron could be considered an endoclone, functionally equivalent to cell clones (or to its part). We hypothesize that the presence of a single giant cell may be considered an alternative to the multi- ple cell system; in other words, a giant or large neuron could be regarded as a "single cell ganglion" combining the properties of many equivalent cells. This evolutionary trick could be useful from a functional point of view as well, since it allows an increase in cell functionality without affecting the tissue structure or its organization. Moreover, the presence of a single endoreplicated neuron could facilitate the functionality of the brain, since a single cell can work without the coordinating system that is necessary in a multiple cell system.

On the other hand, the presence of a unique, multifunctional, and highly active neuron could represent an important weak point in the nervous system, as it makes it more susceptible to damage in comparison to a multiple cell system in which individual damaged or aged cells might be replaced relatively easily. Moreover, a system made up of several cells could be more efficient than a single large neuron in terms of assuring integration of the afferent signals and the successive intracellular transduction of these signals into a more accurate final output.

Data on endoreplication in neurons suggest that it can be obtained by repeated rounds of specific gene amplification or by a complete genome replication. For instance, in the molluscs A. californica, $H$. pomatia, and L. stagnalis, neuronal DNA contents vary by incremental duplications of the whole genome, whereas in the land snail A. fulica, in the planorbid P. corneus, and in all endoploid vertebrate neurons studied, a differential amplification of specific DNA sequences has been reported. This difference could be due to the absence of clustering in amplicons of those DNA sequences whose amplification is necessary in order to satisfy neuron functional requirements in A. californica, $H$. pomatia, and L. stagnalis. The presence of a DNA endoreplication consisting of rounds of amplification of specific gene sequences instead of one complete genome replication represents an evolutionary advantage, as the amplification of unnecessary DNA sequences can be avoided. 
A further discrepancy seems to be related to the observed differences in the amplified genomic compartments. For example, L. piscatorius and P. comeus amplify predominantly GC-rich DNAs, whereas $D$. holacanthus and some molluscs do not show any preferential AT- or GC-rich DNA amplification. In this regard, the availability of techniques such as FACS could lead to better evaluations and, in turn, interesting data that could then be analyzed at a genome level with quantitative methods (like Real Time PCR) in order to identify the DNA sequences that have been amplified in each species. However, the reported discrepancy in results is not necessarily controversial, as amplicons can consist of genes whose proteins are essential for cells and DNA sequences that "go along for the ride" because of their association with other functionally important genes. This endoreplication feature suggests that the differential amplification that occurs in $L$. piscatorius and $D$. holacanthus does not reflect different functions of $\mathrm{SN}$, but only a difference in the type of DNA sequences that are amplified passively because of their proximity to the functionally important ones. This result could simply be due to differences in genome organization that occur in the two phylogenetically distant fish species that were studied, and a similar hypothesis could explain the data observed in molluscs as well.

At the same time, the discontinuous presence of DNA endoreplication in neurons at a phylogenetic level leads us to suggest that endoreplication has been independently "reinvented" several times during both mollusc and teleost evolution. This also supports the hypothesis that the increase in DNA content may be due to different mechanisms that, in some species, lead to replication of the whole genome but, in others, bring about specific gene amplification (Sun and Deng 2005; Sun et al. 2008). Interesting evidence for this can be seen in the two species of puffer fish whose genomes have been sequenced (Jaillon et al. 2004), thus making puffers useful models for the study of endoreplication in neurons. Also, the availability of the whole sequenced genome of the mollusc A. califormica (http://www.broadinstitute .org/science/projects/mammals-models/ vertebrates-invertebrates/aplysia/aplysiagenome-sequencing-project) provides us with the opportunity to study endoreplication from an evolutionary point of view through the comparison of molluscs and puffers. Furthermore, the availability of different EST libraries, both in puffers and molluscs, could furnish important data for identifying genes that undergo endoreplication, thereby allowing us to more accurately define the precise functional roles of endoreplication in neurons.

Despite the available results, a number of substantial and intriguing questions still remain. For instance, which genetic programs mediate the switch to endoreplication? What programs define which cell types will undergo endoreplication? How frequently did novel mechanisms for endoreplication arise during evolution? Answers to these questions may provide new and important insights into cell differentiation and functioning that pertain not only to endoreplication, but to the mechanisms used in proliferation cycles and the growth control of neurons as well. Genomic and transcriptomic analyses could bring about future improvements in our understanding of endoreplication in neurons, providing us with new perspective on the role it plays in the nervous system.

\section{ACKNOWLEDGMENTS}

The authors wish to thank Professor E. W. Roubos (Centre for Neuroscience, Radboud University Nijmegen, The Netherlands) for critical reading and corrections to the manuscript.

\section{REFERENCES}

Anisimov A. P. 2005. Endopolyploidy as a morphogenetic factor of development. Cell Biology International 29:993-1004.

Benedetti I., Sassi D., Mescoli G., Manicardi G. C.
1999. High values of DNA content in the hypothalamic neurons of Lophius piscatorius and Diodon holacanthus (Osteichthyes). Caryologia 52:141-146. Bernocchi G., Barni S. 1985. On the heterogeneity of 
Purkinje neurons in vertebrates. Cytochemical and morphological studies of chromatin during eel (Anguilla anguilla L.) life cycle. Journal für Hirnforschung 26:227-235.

Boer H. H., Groot C., De Jong-Brink M., Cornelisse C. J. 1977. Polyploidy in the freshwater snail Lymnaea stagnalis (Gastropoda Pulmonata): a cytophotometric analysis of the DNA in neurons and some other cell types. Netherland Journal of Zoology 27: 245-252.

Bohn R. C., Mitchell R. B. 1976. Cytophotometric identification of tetraploid Purkinje cells in young and aged rats. Journal of Neurobiology 7:255-258.

Brodsky V., Uryvaeva I. V. 1985. Genome Multiplication in Growth and Development. Cambridge (UK): Cambridge University Press.

Bullock T. H., Horridge G. A. 1965. Structure and Function in the Nervous System of Invertebrates, Volume II. San Francisco (CA): W. H. Freeman.

Chase R., Tolloczko B. 1987. Evidence for differential DNA endoreplication during the development of a molluscan brain. Journal of Neurobiology 18:395406.

Coggeshall R. E. 1972. Autoradiographic and chemical location of 5-hydroxytryptamine in identified neurons in the leech. Anatomical Record 172:489498.

Coggeshall R. E, Yaksta B. A., Swartz F. J. 1970. A cytophotometric analysis of the DNA in the nucleus of the giant cell, R-2, in Aplysia. Chromosoma 32:205-212.

Cohen J., Mares V., Lodin Z. 1973. DNA content of purified preparations of mouse Purkinje neurons isolated by a velocity sedimentation technique. Journal of Neurochemistry 20:651-657.

Cowden R. R. 1972. Cytological and cytochemical examination of the neuronal nuclei of the central nervous systems of Pulmonate Gastropods and some other molluscs. Trans American Microscopy Society 91:130-143.

Cuoghi B. 2001. Glial cells: basic components of clusters of supramedullary neurons in pufferfish. Journal of Neurocytology 30:503-513.

Cuoghi B., Marini M. 2001. Ultrastructural and cytochemical features of the supramedullary neurons of the pufferfish Diodon holacanthus (L.) (Osteichthyes). Tissue E Cell 33:491-499.

Cuoghi B., Mola L. 2007. Morphological, cytochemical, and cytofluorimetric features of supramedullary neurons of the fish Solea ocellata. Biological Bulletin 212:1-5.

Del Monte U. 2006. The puzzle of ploidy of Purkinje neurons. Cerebellum 5:23-26.

Edgar B. A., Orr-Weaver T. L. 2001. Endoreplication cell cycles: more for less. Cell 105:297-306.

Frazier W. T., Kandel E. R., Kupfermann I., Coggeshall R. E. 1967. Morphological and functional properties of identified neurons in the abdominal ganglion of Aplysia californica. Journal of Neurophysiology 30:1288-1351.

Fujita S., Hattori T., Fukuda M., Kitamura T. 1974. DNA contents in Purkinje cells and inner granule neurons in the developing rat cerebellum. Development, Growth and Differentiation 16:205-211.

Fukuda M., Bohm N., Fujita S. 1978. DNA constancy in neurons of the rat and human cerebellum. Progress in Histochemistry and Cytochemistry 11:20-24.

Funakoshi K., Katoda T., Atobe Y., Nakamo M., Goris R.C., Kishida R. 1998. Gastrin/CCK-ergic innervation of cutaneous mucous gland by the supramedullary cells of the puffer fish Takifugu niphobles. Neuroscience Letters 258:171-174.

Gaskell J. F. 1919. Adrenalin in annelids. Journal of Physiology 2:73-85.

Gillette R. 1991. On the significance of neuronal giantism in gastropods. Biological Bulletin 180:234240.

Herman C. J., Lapham L. W. 1969. Neuronal polyploidy and nuclear volume in cat central nervous system. Brain Research 15:35-48.

Howell W. M. 1977. Visualization of the ribosomal gene activity: silver stains proteins associated with rRNA transcribed from oocyte chromosomes. Chromosoma 62:361-367.

Hubbell H. R. 1985. Silver staining as an indicator of active ribosomal genes. Stain Technology 60:285294.

Jaillon O., Aury J., Brunet F., Petit J. L., StangeThomann N., Mauceli E. 2004. Genome duplication in the teleost fish Tetraodon nigroviridis reveals the early vertebrate proto-karyotype. Nature 431: 946-957.

Kandel E. R. 1976. Cellular Basis of Behavior: An Introduction to Behavioral Neurobiology. San Francisco (CA): W. H. Freeman.

Kirsanova I. A., Anisimov A. P. 2000. Somatic polyploidy in neurons from gastropod mollusks. I. Morphological characteristics of ganglia and neurons in the CNS of the snail Succinea lauta. Tsitologiia 42:733-739.

Kühlmann D. 1969. Determination of the DNA content in cell nuclei of the nerve tissue of Helix pomatia L. and Planorbarius corneus L. (Atylomatophora and Basommatophora, Gastropoda). Experientia 25:848-849.

Lasek R. J., Dower W. J. 1971. Aplysia californica: analysis of nuclear DNA in individual nuclei of giant neurons. Science 172:278-280.

Lilly M. A., Duronio R. J. 2005. New insights into cell cycle control from the Drosophila endocycle. Oncogene 24:2765-2775.

Lombardo F., Baraldi E., Sonetti D. 1980. Differential staining and fluorescence of chromatin in popu- 
lation of neuronal nuclei from Planorbis corneus. Nucleus 23:30-36.

Lombardo F., Sonetti D. 1977. The neuronal nuclei in the central ganglia of Planorbid snails. Nucleus 20:271-277.

Lombardo F., Sonetti D. 1983. Amplification and under-replication of repetitive DNAs in the neuronal nuclei of Planorbis corneus. Neuroscience Letters Supplement 14:226.

Manfredi Romanini M. G., Fraschini A., Bernocchi G. 1972. DNA content and nuclear area in the neuronsneurons of the cerebral ganglionganglion in Helix pomatia. Annales d'histochimie 18:49-58.

Mann D. M. A, Yates P. O., Barton C. M. 1978. The DNA content of Purkinje cells in mammals. Journal of Comparative Neurology 180:345-347.

Mares V., Lodin Z., Sácha J. 1973. A cytochemical autoradiographic study of nuclear DNA in mouse Purkinje cells. Brain Research 53:273-289.

Mola L., Cuoghi B. 2004. The supramedullary neurons of fish: present status and goals for the future. Brain Research Bulletin 64:195-204.

Mola L., Cuoghi B., Mandrioli M., Marini M. 2001. DNA endoreplication in the clustered supramedullary neurons of the pufferfish Diodon holacanthus L. (Osteichthyes). Histochemical Journal 33:59-63.

Narbonne-Reveau K., Senger S., Pal M., Herr A., Richardson H. E., Asano M., Deak P., Lilly M. A. 2008. APC/CFzr/Cdh1 promotes cell cycle progression during the Drosophila endocycle. Development 135:1451-1461.

Picciotto M. R., Johnshon R., Schellers R. M. 1986. Neuropeptide genes are not selectively amplified in Aplysia polyploid neurons. Neurology and Neurobiology 20:429-434.

Sassi D., Manicardi G. C., Mola L., Benedetti I. 1995. Cytofluorimetric evidence for differential genome endoreplication in the cluster neurons of Lophius piscatorius L. (Osteichthyes, Lophiiformes). European Journal of Histochemistry 39:117-126.

Smith A. V., Orr-Weaver T. L. 1991. The regulation of the cell cycle during Drosophila embryogenesis: the transition to polyteny. Development 112:997-1008.

Sumner A. T. 1990. Chromosome Banding. London (UK): Unwin Hyman.

Sun J., Deng W.-M. 2005. Notch-dependent downregulation of the homeodomain gene cut is required for the mitotic cycle/endocycle switch and cell differentiation in Drosophila follicle cells. $D e^{-}$ velopment 132:4299-4308.

Sun J., Smith L., Armento A., Deng W.-M. 2008. Regulation of the endocycle/gene amplification switch by Notch and ecdysone signaling. Journal of Cell Biology 182:885-896.

Traas J., Hülskamp M., Gendreau E., Höfte H. 1998. Endoreplication and development: rule without dividing? Current Opinion in Plant Biology 1:498503.

Varmuza S., Prideaux V., Kothary R., Rossant J. 1988. Polytene chromosomes in mouse trophoblast giant cells. Development 102:127-134.

White M. J. D. 1973. Animal Cytology and Evolution. Third Edition. Cambridge (UK): Cambridge University Press.

Zimmet J., Ravid K. 2000. Polyploidy: occurrence in nature, mechanisms, and significance for the megakaryocyte-platelet system. Experimental Hematology 28:3-16.

Zottoli S. J., Akanki F. R., Hiza N. A., Ho-Sang D. A., Jr., Motta M., Tan X., Watts K. M. 1999. Physiological characterization of supramedullary/dorsal neurons of the cunner Tautogolabrus adspersus. Biological Bulletin 197:239-240.

Zybina E. V., Zybina T. G. 1996. Polytene chromosomes in mammalian cells. International Review of Cytology 165:53-119.

Handling Editor: Gregory A. Wray 